\title{
LIVER DAMAGES AND NUCLEAR ABNORMALITIES IN ERYTHROCYTES OF Atherinella brasiliensis (ACTYNOPTERIGII, ATHERINOPSIDADE) FROM TWO BEACHES IN SOUTHEAST OF BRAZIL
}

\author{
Welingtom S. Fernandez ${ }^{2}$; June Ferraz Dias ${ }^{2}$; Ciro Alberto Oliveira Ribeiro ${ }^{3}$ and Juliana de Souza Azevedo ${ }^{1 *}$
}

${ }^{1}$ Instituto de Pesquisas Energéticas e Nucleares (IPEN)

(Av. Prof. Lineu Prestes, 2242, 05508-900 São Paulo, SP, Brasil)

${ }^{2}$ Instituto Oceanográfico da Universidade de São Paulo

(Praça do Oceanográfico, 191, 05508-120 São Paulo, SP, Brasil)

${ }^{3}$ Universidade Federal do Paraná

Departamento de Biologia Celular

(Caixa-Postal: 19031, 81.531-980 Curitiba, PR, Brasil)

*Corresponding author: julianaazevedo_1978@yahoo.com.br

\section{A B S T R ACT}

There are few environmental studies using biomarkers for the species Atherinella brasiliensis in Brazil. In the present work, the presence of hepatic histopathological lesions and nuclear abnormalities in erythrocytes were investigated in A. brasiliensis from Lamberto, a beach under influence of domestic wastes and marine activities. For comparison, fish were also sampled in Puruba, a non-polluted beach, located in the northeastern of São Paulo State. The frequency of lesions found in liver was in higher numbers in individuals from Lamberto than Puruba beach. The most critical injuries observed in A. brasiliensis were the presence of necrotic areas, leucocytes infiltration and piknotic nucleus. A high occurrence of cells with vacuolization was also observed. The hepatic lesion index of the fish from Lamberto beach showed significant high values $\left(\mathrm{I}_{\text {org }}=13\right)$ when compared with fish from Puruba beach ( $I_{\text {org }}=7$ ) suggesting the influence of the several human activities in the studied site. Notched and blebed nucleous were observed in this study, and significant differences were found between the studied sites. However, these differences did not reflect the total nuclear alterations.

\section{RESUMO}

Existem poucos estudos no Brasil usando biomarcadores em Atherinella brasiliensis. No presente trabalho foram investigadas a presença de lesões histopatológicas hepáticas e as alterações nucleares em eritrócitos de A. brasiliensis amostrados na praia do Lamberto, local submetido à influência de resíduos domésticos e atividades humanas. Para comparação, indivíduos da espécie foram também amostrados na praia de Puruba, local não impactado, localizado no noroeste do estado de São Paulo. Peixes provenientes da praia do Lamberto apresentaram lesões hepáticas em número maior do que aqueles da praia de Puruba. Áreas necróticas, infiltração de leucócitos e núcleos picnóticos foram os danos de maior importância observados em A. brasiliensis, apesar de uma elevada ocorrência de vacuolização também ter sido verificada. O índice de lesão hepática dos peixes da praia do Lamberto mostrou valores significantemente maiores $\left(\mathrm{I}_{\mathrm{org}}=13\right)$ quando comparados com o dos peixes da praia de Puruba $\left(I_{\text {org }}=7\right)$, sugerindo influência das diversas atividades humanas existentes na área avaliada. Em relação aos núcleos "notched" e "blebed", foram observadas diferenças significativas entre as áreas, mas não para as alterações nucleares totais.

Descriptors: Histopathology, Nuclear abnormalities, Atherinella brasiliensis, biomonitoring, Brazilian Coast.

Descritores: Histopatologia, Alterações nucleares, Atherinella brasiliensis, biomonitoramento, Costa brasileira.

\section{INTRODUCTION}

The discharge of chemicals by industrialization process affects the aquatic environments. The estuaries are under high influence of urban, industrial, harbor and agricultural activities (LIVINGSTONE, 1993, 1998; OLIVEIRA RIBEIRO et al., 2005; VALDEZ DOMINGOS et al., 2007; 
AKAISHI et al., 2007). Furthermore, organisms are exposed to a complex mixture of contaminants as toxic metals, organoclorides compounds, polycyclic aromatic hydrocarbons (PAHs) and sewage, and due to the dynamics of hydrographical and geomorphological conditions the bioavailability can increase. In addition, other aspects as stage of life cycle, development of tolerance and abiotic factors as temperature, water hardness, $\mathrm{pH}$ and salinity must be considered (BOENING, 2000). Fish has been considered good indicators for environmental studies due to the facility to accumulate pollutants in target tissues, and transferring them to higher trophic levels (FISK et al. 2001; BOON et al. 2002; OLIVEIRA RIBEIRO et al., 2005).

Although qualitative analysis are more frequently used in pathological studies caused by chemical compounds, the integration of the qualitative and quantitative analyses supply better evidences about the pollutant reactions in the organisms (JAGOE, 1996). The chemical exposure causes damages in different levels of biological organization and may be measured by histological, genetic and physiological findings. Chemical stress induces alterations in metabolic functions in both cellular and organ levels (AYAS et al., 2007).

Histopathological endpoints is an important method to evaluate the toxic effects caused by contaminants and can also provide more knowledge about the mechanisms of action and target organs, necessary for further characterizing the risk of toxic compounds (WESTER et al., 2002). Cellular biomarkers act as early warning signal of stress suffered by organisms exposed to contamination and may provide information on the level of the developing stress syndrome from starting biological effects to the impact on the cell physiology. An assessment of fish health status monitoring liver lesions in free-roaming populations has recently been recommended as a consequence of several studies performed in European and North America sea waters (LYONS et al., 2004).

Fish tissues are potentially able to bioaccumulate inorganic and organic compounds (OLIVEIRA RIBEIRO et al., 2005). In addition, the chemical exposition can induce several lesions and injuries in different organs of fish through laboratory assays (RABITTO et al., 2005; MELA et al., 2006) or in field studies (OLIVEIRA RIBEIRO et al., 2005; MIRANDA et al., 2008). The histopathological lesions and the nuclear abnormalities are used as biomarkers due to its fast and easy interpretation (HEDDLE et al., 1991; BOMBAIL et al., 2001).

Atherinella brasiliensis is a small pelagic fish species reaching a total length of $169 \mathrm{~mm}$. Its diet varies from copepods, shirimps, amphipods to tanaidaceans and smaller fish. This species is widely distributed, from Venezuela to the South of Brazil as a member of the most common in haul of beaches and estuaries in the southeast-south coast of Brazil (FIGUEIREDO; MENEZES, 1978).

The current work presents histopathological alterations on liver and nuclear abnormalities in blood of A. brasiliensis from two beaches in the Brazilian coast, with different human activities. The aim of this work is also to improve knowledge about histopathological and genotoxic biomarkers for $A$. brasiliensis representing the first study with this species as bioindicator in Brazilian coast.

\section{Material and Methods}

Sampling Stations

The Puruba beach was used as reference site since it is a well preserved site located at $23^{\circ} 23^{\prime} \mathrm{S}$; $44^{\circ} 56^{\prime} \mathrm{W}$ at Ubatumirim Bay. The environmental protected area from "State Park of Serra do Mar", with $2 \mathrm{~km}$ of extension (Fig. 1). The second beach, called Lamberto, is smaller with $50 \mathrm{~m}$ of extension, located at Flamengo Bay $\left(23^{\circ} 30^{\prime} \mathrm{S} ; 45^{\circ} 07^{\prime} \mathrm{W}\right)$ and under the influence of urban and harbor activities with approximately a thousand of small motor and artisanal fishery boats. Additionally, the municipal pier is located also in this area increasing the discharges sources (Fig. 1).

\section{Fish and Procedures}

A total of 20 adult specimens of Atherinella brasiliensis were collected in two beaches in February of 2006, using a beach seine $(9 \times 1.5 \mathrm{~m}$, with $10 \mathrm{~mm}$ mesh central and $20 \mathrm{~mm}$ mesh lateral). In the laboratory morphometric data of each fish was taken, for instance total length, total weight and sex. Liver and blood samples were taken and prepared for histopathological and nuclear alterations analysis, respectively.

The liver was sampled after fish have been anesthetized with benzocaine ( $2 \%$ in water) and killed by spinal section, and preserved in Alfac fixative solution $(85 \%$ alcohol at $80 \%, 10 \%$ formalin at $40 \%$ and $5 \%$ acetic acid) for $16 \mathrm{~h}$, dehydrated in a graded series of ethanol baths, and embedded in ParaplastPlus resin (Sigma) for histopathological examination. Five-micrometer-thick sections were obtained and stained in Haematoxylin/Eosin for light microscopy analysis (OLIVEIRA RIBEIRO et al., 2005) and studied trough lesion index methods according to Bernet et al. (1999). 


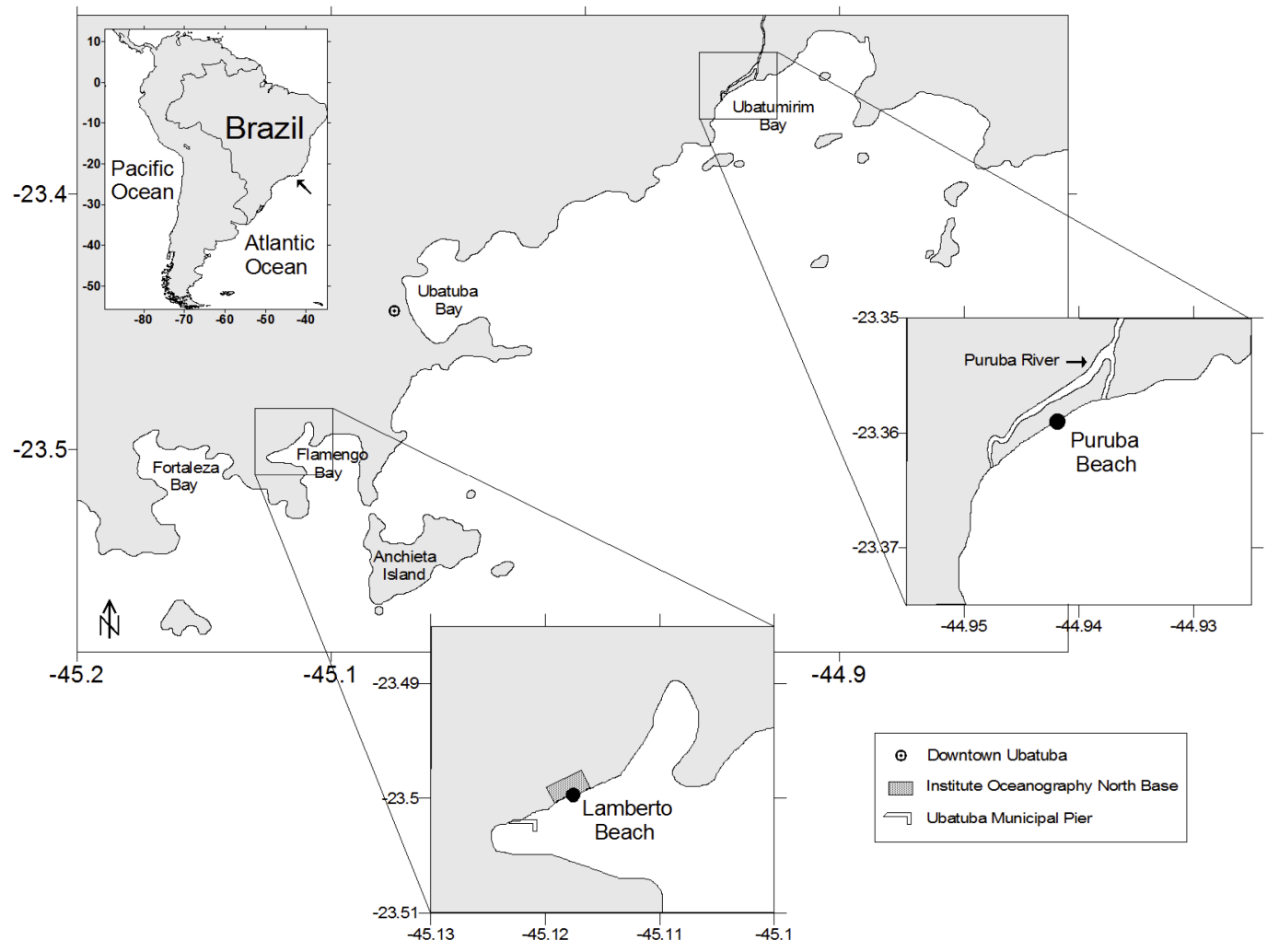

Fig. 1. Map of studied area with the sampling sites at Lamberto and Puruba beaches, Ubatuba southeastern Brazilian coast.

Slides containing blood smears of $A$. brasiliensis were examined to investigate the presence of micronuclei and other nuclear abnormalities in the circulating erythrocytes. Blood samples were obtained by caudal vein puncture using a syringe. Blood was smeared immediately onto two clear glass slides, air dried, and then fixed in absolute methanol for $10 \mathrm{~min}$. Each slide was stained with $10 \%$ Giemsa solution for $30 \mathrm{~min}$ and 2000 erythrocytes were scored under 1000 $\mathrm{x}$ magnification to determine the frequency of micronuclei and other nuclear abnormalities were counted for each specimen. The nuclear lesions observed were classified into categories following Carrasco et al. (1990).

\section{Statistical Analysis}

For histopathological analysis KolmogorovSmirnov test. Kruskal-Wallis (K-W) and the Chisquare test were applied to lesions occurrence using the lesion index. The frequencies of nuclear lesions were expressed per 2000 cells and the differences were analyzed by Student $t$ test. The results were considered statistical significant if $p$-Value $<0.05$.

\section{Results}

A. brasiliensis from reference beach are bigger in size and weight when compared with the study area (respectively $123.10 \pm 11.5 \mathrm{~mm}$ and 12.14 $\pm 3.8 \mathrm{~g}$, and $79.80 \pm 6.4 \mathrm{~mm}$ and $3.31 \pm 0.8 \mathrm{~g}$ ), with active gonadal maturation, including spawning and post-spawning individuals, but only immature individuals were collected in the studied area.

In general, no morphological lesions as fungi infestations, inflammations, parasites or tumors were observed. The general hepatic morphology revealed that the hepatocytes are typically organized in compact groups of polyhedral cells as observed in other teleosts species (Fig. 2A). The specimens from both studied sites presented small differences concern to the lesions observed in this tissue (Table 1). The majority of the individuals from both the reference and studied sites presented necrotic areas (Fig. 2B), inflammatory response (Fig. 2C) and cytoplasme vacuolization not related with glycogen deposits (Fig. 2D) but the macrophage aggregates normally found in liver of this species were absent. Eventually, inflammatory responses as leucocytes infiltration associated to necrotic lesions were found, but in low frequencies 
(Table 1). Enlarged hepatocytes containing pyknotic nucleus were observed in livers from the polluted beach (Fig. 2E). A vermiforme parasite was also observed in some fish (Fig. 2F). Despite of the occurrence of some lesions in the liver of individuals from both sites, the occurrence of necrosis was higher in individuals from the impacted site.

The values of the lesion index estimated were significantly higher in the individuals from polluted in relation to the non-polluted area $(p<0.05)$ (Fig. 3).
Nuclear abnormalities in the erythrocytes of A. brasiliensis were analyzed, quantified and classified. Significant differences $(p<0.05)$ were observed between individuals from studied and reference beaches, concerning notched and blebed nucleus (Table 2). However, the total nuclear abnormalities did not differ significantly and micronucleus was not observed. These data suggest no occurrence of genotoxic pollutants in the studied areas.

Table 1. Prevalence $(\%)$ of the alterations for liver observed in Atherinella brasiliensis from Lamberto and Puruba beaches.

\begin{tabular}{lcc}
\hline \hline \multicolumn{1}{c}{ Lesions } & $\begin{array}{c}\text { Studied site } \\
\text { (Lamberto beach) }\end{array}$ & $\begin{array}{c}\text { Reference site } \\
\text { (Puruba beach) }\end{array}$ \\
\hline Necrotic areas & 100 & 60 \\
Fat vacuolization & 90 & 90 \\
Leucocytic infiltration & 20 & 10 \\
Pyknotic nucleus * & 30 & 0.0 \\
Tissue differentiation * & 10 & 0.0 \\
Vermiforme parasites & 0.0 & 10 \\
$* p<0.001$. & &
\end{tabular}
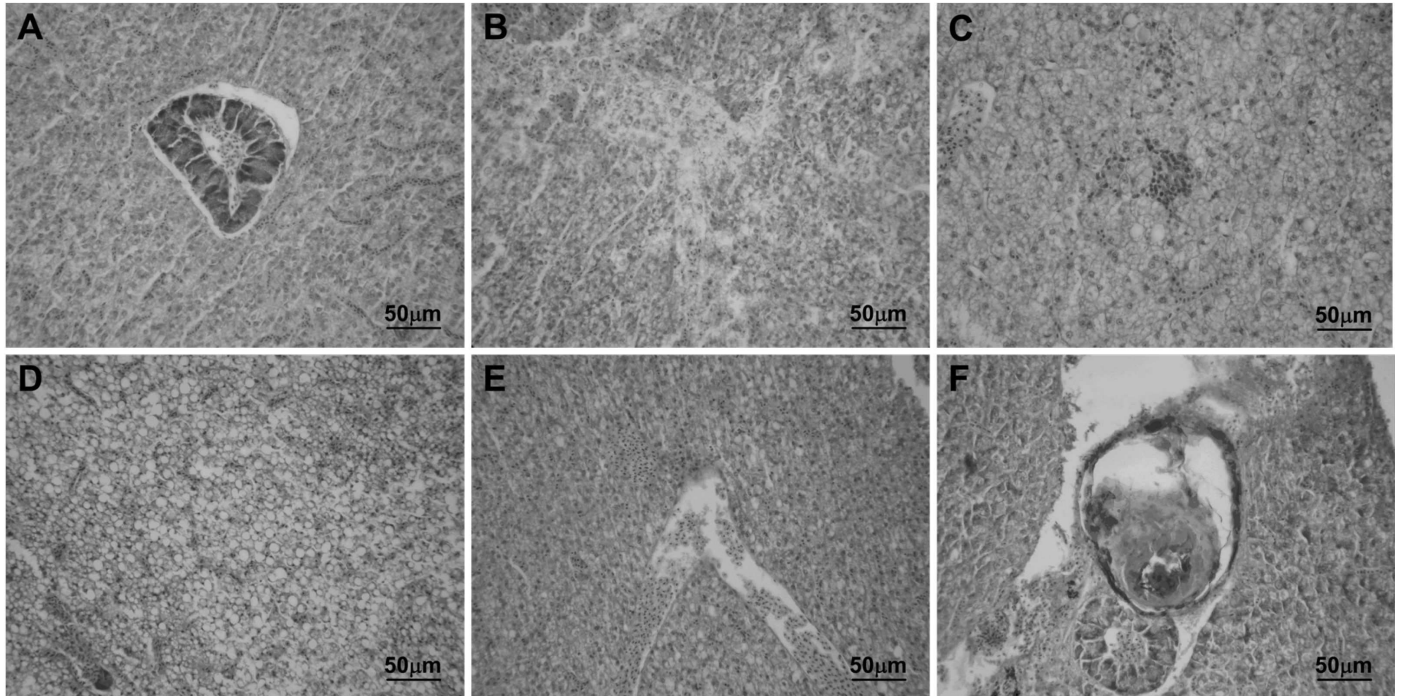

Fig. 2. Liver cross section of Atherinella brasiliensis stainned with hematoxylin and eosin. (A) Normal tissue; (B) Large necrotic area; (C) Inflammatory response; (D) Vacuolated area of the liver; (E) Pyknotic nucleus; (F) Transversal view of one vermiforme parasite. 


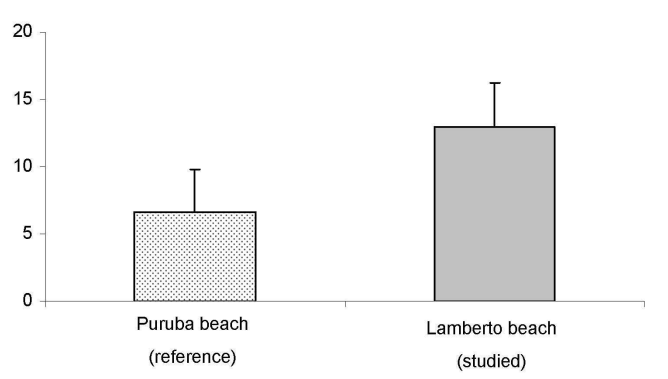

Fig. 3. Lesions Index in the liver of Atherinella brasiliensis from reference (Puruba) and studied (Lamberto) beaches. Lamberto beach results were significative at $p<0.05$.

Table 2. Prevalence (\%) of nuclear abnormalities in erythrocytes of Atherinella brasiliensis from Lamberto and Puruba beaches.

\begin{tabular}{lcc}
\hline \hline $\begin{array}{c}\text { Nuclear } \\
\text { abnormalities }\end{array}$ & $\begin{array}{c}\text { Studied site } \\
\text { (Lamberto beach) }\end{array}$ & $\begin{array}{c}\text { Reference site } \\
\text { (Puruba beach) }\end{array}$ \\
\hline Notched * & 0.15 & 0.6 \\
Lobed * & 0.16 & 0.4 \\
Blebed & 0.0 & 0.03 \\
Binuclei cell & 0.0 & 0.006 \\
Vacuolizated & 0.0 & 0.01 \\
Micronuclei & 0.0 & 0.0 \\
Others * & 0.04 & $0.15^{\mathrm{b}}$ \\
\hline$p<0.005$. & &
\end{tabular}

\section{Discussion}

The usefulness of histopathological and erythrocytes nuclear abnormalities as biomarkers can give an overview of possible effects caused by pollutants, but it cannot be linked with cause-effect.

The melanomacrophage centers, are indicative of removal of foreign particles or products of the cellular degradation by phagocytosis (Rabitto et al., 2005) and these centers can also be considered non specific indicator of exposure to environmental contaminants (AU, 2004). The absence of melanomacrophages centers may be associated with the exposure to pollutants associated with immunodepresive mechanisms as organochlorines (MIRANDA et al., 2008). On the other hand, A. brasilienses presented occurrence of fat vacuolization in both, polluted and non-polluted environment. The presence of vacuolization can be related with the presence of PAHs or effects of contaminants in the water that can interfere with vesicles traffic and as consequence accumulation of secretion product (OLIVEIRA RIBEIRO et al., 2005). On the other hand, the association with the metabolic mechanism of the fish cannot be discarded.

The pyknotic nuclei are related with the degree of cell metabolic activity (ALBERTS et al., 2002). The presence of pyknotic nucleus in fish from impacted beach can be related with cell death. This standard suggests a mechanism of energy reserve in specimens submitted to some stress in the environment. In addition, the metabolic activity can be also linked to the intrinsic biological processes of $A$. brasiliense from the impacted beach, since all the individuals collected were juveniles and therefore most of the energy expense is direct to growth and developmental processes during this phase of the life cycle (FUIMAN; WERNER, 2002). On the other hand, a according to Roberts (1981) and Heath (1995) fish fed properly, their hepatocytes are usually full of glycogen and neutral fat, however, during periods of stress response, there may be three different situations: a) the alarm phase, occurs the mobilization of liver glycogen, b) the phase of resistance and adaptation, glycogen can be found at low levels or not, and c) the stage of exhaustion, can occur depletion of liver glycogen.

Leucocytes infiltration is a sign of inflammatory process, that can be associated the several factors, thus not being able to be identified an only cause (BERNET et al., 1999). In general, leucocytes infiltrations are associated with the necrotic areas, justifying an increase of leucocytes infiltration for the fish from impacted beach in relation to the fish from non-polluted beach. The majority of pollutants are able to cause cell death and depending on the gravity of the lesion can develop to large necrosis area, and consequently increasing inflammatory response in the tissue, as reported by others (OLIVEIRA RIBEIRO et al., 2005; MIRANDA et al., 2008).

The individual analysis of Bernet et al. (1999) index for each lesion (ei. necrosis; fat vacuolization; leucocytes infiltration; tissue diferentiation as the presence of areas was observed a coloration changes or tissue arrangement disturb; and piknotic nucleus) shows that the fish specimens from polluted site presented more damages than nonpolluted beach. The most representative lesions in these fish were the irreversible injuries that can cause a total or partial loss of organ function. However, cytoplasme vacuolization, a reversible and moderate alteration, was the most representative in the fish from reference beach, and it can be a product of metabolic processes of individual fish. This alteration can be considered a reservation in these individuals, but it cannot be discarded the possibility of PAHs exposure. 
As the fish from polluted beach showed also highest values for liver lesion index $\left(\mathrm{I}_{\text {org }}\right)$ than fish from nonpolluted beach, showing that values from the impacted beach reflects the group of alteration observed in the tissue.

Nuclear morphologic abnormalities are successful in biomonitoring studies therefore to detect genotoxic products and damage in fish (HAYASHI et al., 1998; AYLLON; GARCIA-VAZQUEZ, 2000; GRISOLIA; STARLING, 2001; PORTO et al., 2005). Ateeq et al. (2002) considers that abnormal morphological forms of erythrocytes are effective indicators of cytotoxicity. Additionally, nuclear abnormalities analyze is considerate the more common cytogenetic techniques due its large sensitivity to the cytotoxic effects cell the pollutant exposition. (ÇAVAS et al., 2005). Our results indicated that the total nuclear abnormalities did not differ significantly between the areas. In spite of these data suggest no occurrence of genotoxic pollutants in the studied areas, the composition and quantification of the contaminants in the beaches can vary markedly and additional studies must be performed. It must be kept in mind that the histopathological and nuclear analyses are generalized and not specific, and that the findings here could be a result of multiple impacts in the area, including sewer.

\section{ACKNOWLEDGMENTS}

This work was supported by CAPES (Brazilian Agencies for Science and Technology) and Oceanographic Institute of the São Paulo University.

\section{REFERENCES}

AKAISHI, F. M.; ST-JEAN, S. D.; BISHAY, F.; CLARKE, J.; RABITTO, I. S.; OLIVEIRA RIBEIRO, C.A. Immunological responses, histopathological finding and disease resistance of blue mussel (Mytilus edulis) exposed to treated and untreated municipal wastewater. Aquat. Toxicol., v. 82, n. 1, p. 1-14, 2007.

ALBERTS, B.; JOHNSON, A.; LEWIS, J.; RAFF, M. ROBERTS, K.; WALTER, P. Molecular Biology of the cell. 4th ed. New York: Garland Science, 2002.

ATEEQ, M. B.; FARAH, M. A.; ALI, N.; AHMAD, W. Induction of micronuclei and erythrocyte alterations in the catfish Clarias batrachus by 2,4dichlorophenoxyacetic acid and butachlor. Mutation Res., v. 518, p. 135-144, 2002.

AU, D. W. T. The application of histo-cytopathological biomarkers in marine pollution monitoring: a review. Mar. Pollut. Bull., v. 48, p. 817-834, 2004.

AYAS, Z.; EKMEKCI, G.; OZMENB, M.; YERLI, S.V. Histopathological changes in the livers and kidneys of fish in Sariyar Reservoir, Turkey. Environ. Toxicol. Pharmacol., v. 23, p. 242-249, 2007.
AYLLON, F.; GARCIA-VAZQUEZ, E. Induction of micronuclei and other nuclear abnormalities in European minnow Phoxinus phoxinus and mollie Poecilia latipinna: an assessment of the fish micronucleus test. Mutation Res., v. 467, p. 177-186, 2000.

BERNET, D.; SCHMIDT, H.; MEIER, W ; BURKHARDTHOLM, P.; WAHLI, T. Histopathology in fish: proposal for a protocol to assess aquatic pollution. J. Fish. Dis., v. 22, p. 25-34, 1999.

BOENING, D. W. Ecological effects, transport, and fate of mercury: a general review. Chemosphere, v. 40, p. 1335-1351, 2000.

BOMBAIL, V.; AW, D.; GORDON, E.; BATTY, J. Application of the comet and micronucleus assay to butterfish (Pholis gunnellus) erythrocytes from the Firth of Forth, Scotland, Chemosphere, v. 44, p. 383-392, 2001.

BOON, J.P.; LEWIS,W.E.; CHOY, M.R.; ALLCHIN, C.R.; LAW R.J.; de BOER, J. Levels of polybrominated diphenyl ether (PBDE) flame retardants in animals representing different trophic levels of the North Sea food web. Environ. Sci. Technol.,v. 36, p. 4025-4032, 2002.

CARRASCO, K. R.; TILBURY, K. L.; MYERS, M. S. Assessment of the Piscine Micronucleus Test as an in situ Biological Indicator of Chemical Contaminant Effects. Can. J. Fish. aquat. Sci., v. 47, p. 2123-2136, 1990.

ÇAVAS, T.; GARANKO, N. N.; ARKHIPCHUK, V. V. Induction of micronuclei and binuclei in blood, gill and liver cells of fishes subchronically exposed to cadmium chloride and copper sulphate. Food Chem. Toxicol., v. 43, p. 569-574, 2005.

FIGUEIREDO, J. L.; MENEZES, N.A. Manual de peixes marinhos do sudeste do Brasil. II. Teleostei (1). São Paulo, Museu de Zoologia da Universidade de São Paulo. São Paulo: Museu de Zoologia da Universidade de São Paulo, 1978. 110 p,

FISK, A. T.; HOBSON, K. A.; NORSTROM, R. J. Influence of chemical and biological factors on trophic transfer of persistent organic pollutants in the Northwater Polynya marine food web. Environ. Sci. Technol., v. 35, p. 732738, 2001.

FUIMAN, L. A.; WERNER, R. G. Fishery Science: The unique contribution of early life stages. Oxford: Blackwell Science, 2002.

GRISOLIA, C. K.; STARLING, F. L. R. M. Micronuclei monitoring of fishes from Lake Paranoá, under influence of sewage treatment plant discharges. Mutation Res., v. 491, p. 39-44, 2001

HAYASHI, M.; UEDA, T.; UYENO, K.; WADA, K.; KINAE, N.; SAOTOME, K.; TANAKA, N.; TAKAI, A.; SASAKI, Y. F.; ASANO, N.; SOFUNI, T.; OJIMA, Y. Development of genotoxicity assay systems that use aquatic or ganisms. Mutation Res., v. 399, p. 125-133, 1998.

HEATH, A. G. Water pollution and fish physiology. 2ed. Florida: CRC Press, 1995.384 p.

HEDDLE, J. A.; CIMINO, M. C.; HAYASHI, M.; ROMAGNA, M. D.; TUCKER, J. D.; VANPRAIS, P. H., McGREGOR, J. T. Micronuclei as a index citogenetic damage: past, presence and future. Environ. Mol. Mutagen., v. 18, p. 277-291, 1991 
JAGOE, C. H. Responses at the tissue level: quatitative methods in histopathology applied to ecotoxicology. In: NEWMAN, M. C., JAGOE, C. H. (Ed.). Ecotoxicology: A hierarchial treatment. New York: Lewis Publishers; CRC Press, 1996.

LYONS, B. P.; STENTIFORD, G. D.; GREN, M.; BIGNELL, J.; BATERMAN, K.; FEIST, S. W.; GOODSIR, F.; REYNOLDS, W. J.; THAIN, J. E. DNA adduct analysis and histopathological biomarkers in European flounder (Platichthys flesus) sampled from UK estuaries. Mutation Res., v. 522, p. 177-186, 2004.

LIVINGSTONE, D. R. Biotechnology and pollution monitoring: use of molecular biomarker in the aquatic environment. J. Chem. Technol. Biotechnol., v. 57, p. 195-211, 1993.

LIVINGSTONE, D. R. The fate of organic xenobiotics in aquatic ecossystems: quantitative and qualitative differences in biotransformation by invertebrates and fish. Comp. Biochem. Physiol., v. 120A, p. 43 - 49, 1998.

MELA, M.; RANDI, M.A.F.; VENTURA, D.F; CARVALHO, C.E.V.; PELLETIER, E., OLIVEIRA RIBEIRO, C.A. Effects of dietary methylmercury on liver and kidney histology in the neotropical fish Hoplias alabaricus. Ecotoxicol. Environ. Saf. <doi:10.1016/j.ecoenv.2006.11.013>.

MIRANDA, A. L.; ROCHE, H.; RANDI, M. A. F.; MENEZES, M. L.; OLIVEIRA RIBEIRO, C. A. Bioaccumulation of chlorinated pesticides and PCBs in the tropical freshwater fish Hoplias malabaricus: Histopathological, physiological, and immunological findings. Environ. Int. <doi:10.1016/j.envint.2008.02.004.
OLIVEIRA RIBEIRO, C. A.; VOLLAIRE, Y.; SANCHEZCHARDI, A.; ROCHE, H. Bioaccumulation and the effects of organochlorine pesticides, $\mathrm{PAH}$ and heavy metals in the Eel (Anguilla anguilla) at the Camargue Nature Reserve, France. Aquat. Toxicol., v. 74, p. 53$69,2005$.

PORTO, J. I. R.; ARAÚJO, C S. O.; FELDBERG, E. Mutagenic effects of mercury pollution as revealed by micronucleus test on three Amazonian fish species. Environ. Res., v. 97, p. 287-292, 2005.

RABITTO, I. S.; ALVES COSTA, J. R. M.; SILVA DE ASSIS, H. C., PELlETIER, E.; AKAISHI, F. M.; ANJOS, A.; RANDI, M. A. F.; OLIVEIRA RIBEIRO, C. A. Effects of dietary $\mathrm{Pb}$ (II) and tributyltin on neotropical fish, Hoplias malabaricus: Histopathological and biochemical findings. Ecotoxicol. Environ. Saf., v. 60, p. 147-156, 2005.

ROBERTS, R. J. Patologia de los peces. Madrid: MundiPrensa, 1981. 366 p.

VALDEZ DOMINGOS, F. X.; AZEVEDO, M.; SILVA, M. D.; RANDI, M. A. F.; FREIRE, C. A.; SILVA DE ASSIS, H. C.; OLIVEIRA RIBEIRO, C. A. Multibiomarker assessment of three Brazilian estuaries using oysters as bioindicators. Environ. Res., v. 105, n. 3, p. 350-363, 2007.

WESTER, P.W; VAN DER VEN, L.T.M ; VETHAAK, A.D., GRINWIS, G.C.M., VOS, J.G. Aquatic toxicology: opportunities for enhancement through histopathology. Environ. Toxicol. Pharmacol., v. 11, p. 289-295, 2002.

(Manuscript received 19 February 2010; revised 12 July 2010; accepted 11 November 2010) 